\title{
Understanding the Importance WhatsApp Group and How Indonesian Students Utilize the Platform in Australia
}

\author{
Syauqy Lukman ${ }^{1}$ \\ \{syauqy.lukman@unpad.ac.id\} \\ Universitas Padjadjaran, Indonesia
}

\begin{abstract}
This study tries to explain the communication pattern of Indonesian students in Australia when using WhatsApp (WA) group, adhering to the Uses and Gratification theory. Utilizing a cross-sectional approach, this participatory study took data from a WA group dedicated to post-graduate students in Australia with financial support from a specific scholarship (L). Data were collected by categorizing WA posts which span from August 2019 to October 2019 and also using online questionnaire distributed to the member of the group. The result of the research provides an insight into how Indonesian students utilize and interacts within the WA group. Findings show variance on how participants in the group interact with another and how they value the importance of the platform.
\end{abstract}

Keywords: WhatsApp, Uses and Gratification, Indonesian Diaspora, Australia

\section{Introduction}

Indonesian diaspora is quite commonly found in Australia since the country boasts plentiful job opportunities and offers some of the best tertiary educations. According to The Australian Department of Home Affairs, the country has granted approximately 40.000 student visa for Indonesian citizen [1]. Living outside of their comfort zone, without family and peer supports, students seek a method to stay connected with their compatriots, and WhatsApp (WA) groups offer such a solution. It is interesting to discover that student members of a WA group would interact differently and also have different values regarding WA group platform.

Seufert, et al, argues that group-based communication in WA constitutes an emerging communication paradigm, in simple words, WA changed the way people communicate, from an IT-network communication perspective [2]. Face to face interpersonal and organizational interactions are greatly reduced due to the usage of WA [3].

WA group is known to be widely used by people from all around the world, be it for family use, a network of friends, for work-professional related activities, and for study purposes [4]. Among the varieties of WA usage, the platform can be utilized for disseminating health information to improve knowledge and engagement [5], promoting events [6], used as a way to maintain communication among family members [7], and can also be used as a platform for coordinating among neighbourhood household members of urban and rural communities [8].

The usage of WA groups in the education field is also quite commonly found in Indonesia. For example, teachers believe WA Group can become an effective way to solve the limitation of lecture-students interactions at class in Indonesia [9]. Lecturers in higher education optimizes WA group as a platform to maintain communication with students throughout the thesis 
supervision process [10]. Faculty members of a university in Bogor that includes lecturers, administrative staff and students, would use WA group as their backbone communication facility to interact with one another, discussing academic topics, disseminating announcements, even post entertaining contents unrelated to the purpose of the creation of the WA Group [11].

Although the platform offers many advantages in making communication easier, there are some issues that arise from it. Naturally, just like any other communication platform, controlling the delivered content would always pose problems to the participants of WA groups. Hoaxes and hate speech can go viral in an instant through this platform, to the extent that Indonesian government would limit the usage of WA [12], and cases of cyberbullying is also known to be apparent within WA group [13].

According to the annual survey from "We Are Social", WA is rated as the second most active social media platform - the first is YouTube, and the most active chatting platform in Indonesia [14]. It is quite obvious for Indonesian to select this platform as the primary social media chatting platform, and that also includes diaspora of Indonesian Students in Australia.

Taking the assumption of Uses and Gratification Theory, by Katz et al., the theory provides a framework for understanding when and how individuals consume media, to be more or less active, and how would the media have an impact on increasing or decreasing of audience involvement [15].

This study would like to find out how group members of a certain WA group interact within the group, identifying their motives in participating in discussions and interactions, types of information needed, and categorizing types of information that is discussed in the group.

\section{Results and Discussion}

This study is a cross-sectional study that utilizes data from a specific WA group that I participate in, with the characteristics of member as follows; 1) Indonesian Student taking higher education in Australia, 2) recipient of "L" scholarship, 3) participated in the same pre-departure workshop in Indonesia. Careful measures should be taken when generalizing the data, as the small population cannot reflect the entire diaspora of Indonesian students in Australia. From the 17 members of the group that includes myself as an observer, 15 samples were taken using selfadministered online questionnaire using Google Forms with 1 non-responsive response.

\section{Demographic Data}

$60 \%$ (9 person) of the respondents are currently enrolled to a Master's programme, while the rest $40 \%$ (6 people) are Ph.D. students. Most students are from Canberra $(60 \%, 9$ person), followed with students from Melbourne (33.3\%, 5 person), from Adelaide $13.3 \%$ (2 person), Sydney $(6.7 \%, 1$ person), and Brisbane $(6.7 \%, 1$ person). The dominant age group is $31-35$ years old (46.7\%, 7 person), followed by $25-30$ years old people $(20 \%), 36-40$ years old $(20 \%)$, with few belongings to the $17-24$ group $(6.7 \%)$, and over 40 years old $(6.7 \%)$. We can conclude that most participants of this study belong the adult category, with only 1 person belonging to the adolescent category. Based on sex, $60 \%$ of the respondents are male, and $40 \%$ are female.

\section{Motivation and Information Needs}

The respondents were provided with open-ended question on their motivation in joining the WA group. To join the group voluntary, with fellow participant inviting/informing the link to join the group to potential group members. We can find the findings in Table 1. The motivation 
of joining the group, includes the need to obtain information related to life in Australia, improving networks, gaining new friends, and getting help from fellow Indonesian students.

Table 1. Motivation to Join Group (open-ended question)

\begin{tabular}{lll}
\hline \multicolumn{1}{c}{ Motivation } & $\mathrm{n}=15$ & percentage \\
\hline Obtaining information related to life in Australia & 13 & $86.67 \%$ \\
Improve Networking & 12 & $80.00 \%$ \\
Gaining new friends & 9 & $60.00 \%$ \\
Getting help from fellow students & 12 & $80.00 \%$ \\
\hline
\end{tabular}

In the next step of this study, respondents were asked on the kinds of information that they expected to receive by joining the group (Table 2.). As we can predict, information related to student's life in Australia are more apparent, that includes information of pre-departures preparation, personal needs, education support, family and dependants, and also events. Interestingly, there are also needs for job opportunities also sales and trades. It is quite common for Indonesian students to take part-time work while pursuing higher degree in Australia, and it also common to conduct sales and trades of products, such as selling food and accommodation rental transactions among students.

Findings described in Table 1 and Table 2 are consistent with the general online information seeking behaviour of students, reflecting on the preference on using WA group due to the ease in offers. Referring to the information seeking behaviour process based on David Ellis' 1989 model: starting $\rightarrow$ chaining $\rightarrow$ browsing $\rightarrow$ differentiating $\rightarrow$ monitoring $\rightarrow$ extracting, which is adapted by Esew et al as: Identifying online sources $\rightarrow$ following links to related pages $\rightarrow$ scanning page lists, heading, site map $\rightarrow$ selecting useful pages, bookmarking, printing, copying, selecting known content $\rightarrow$ receiving site updates, revisiting favourite sites for updated info $\rightarrow$ systematically search sites to extract information of interest. By joining the WA group, the online information seeking behaviour is discounted, allowing fewer resources to obtain specific information which is needed [16].

Table 2. Types of Information needed in the group (open-ended question)

$$
\text { Information }
$$

\begin{tabular}{lll}
\hline Related to pre-departures (visa, LOA, etc.) & 13 & $86.67 \%$ \\
Related to personal needs in Australia & 12 & $80.00 \%$ \\
Related to education support in Australia & 11 & $73.33 \%$ \\
Related to Family and dependants & 11 & $73.33 \%$ \\
Job Opportunities & 6 & $40.00 \%$ \\
Sales and Trades & 6 & $40.00 \%$ \\
Indonesian Students events & 9 & $60.00 \%$ \\
\hline
\end{tabular}




\section{Self-Assessment on Group Interaction and Values}

In the following step of the study, the respondents were provided with 7 questions group that would assess how members would interact with one another and how they value the group (Table 3). Using a 5-scale Likert scale, indices were obtained by attributing a score of 1 for 'strongly disagree', score of 2 for 'disagree', 3 for 'neutral/no opinion', 4 for 'agree', and 5 for 'strongly agree'. Interestingly, most member doesn't consider themselves as active within the group (index=2) and are also neutral on whether they often post good information or not (index=2.5). Members also don't consider the group as an important platform for social existence (index=2.2), meaning that they are not here for self-existence but for the information and help that they can gain from other members of the group.

The members believe that by participating in the group would be beneficial for their education in Australia (index 3.4), with other members always responding to questions (index $=3.5$ ), and with the self-willingness of providing answers for questions by other members (index=3.6).

Consistent to that, members don't believe that participating in the group would waste their time (index $=1.5$ ) and they are mostly comfortable with other members of the group (index $=1.7$, using negative question format). There are many factors that would explain participation in WA Group, such as age, psychological characteristics, group subject, etc [17], for this particular study, the aforementioned predictors are not discussed.

Table 3. Self-Assessment on Group Interaction and Values

\begin{tabular}{lllllll}
\hline & SD & D & N & A & SA & Index \\
\hline Active WA user in the group & 1 & 2 & 3 & 4 & 0 & 2.0 \\
Posting Good Information & 5 & 4 & 3 & 4 & 0 & 2.5 \\
This group is important for social existence & 5 & 6 & 2 & 0 & 2 & 2.2 \\
Beneficial to support education in Australia & 1 & 0 & 7 & 6 & 1 & 3.4 \\
This group is time-wasting & 8 & 6 & 1 & 0 & 0 & 1.5 \\
Members always reply my question & 1 & 1 & 4 & 7 & 2 & 3.5 \\
I always reply questions with known answers & 0 & 2 & 5 & 5 & 3 & 3.6 \\
Not comfortable with members of the group & 7 & 6 & 2 & 0 & 0 & 1.7 \\
\hline
\end{tabular}

To further complete the analysis of interactions within the group, the work proceeds by analysing the types of information that was posted in the group starting from 9 August 2019 (the beginning when the group was created) to 15 October 2019. I carefully categorise posts based on the type content that is being discussed, categorising them into information that are: (1) Group Related, (2) Scholarship-Funds Related, (3) Job related, (4) Pre-Departure Related, (4) Personal Needs/Daily Activities, (5) Student Community related, and (6) Study Process related.

Group-related posts are posts with the content related to technical aspects on participating in the group, such as troubleshooting in posting certain content in the group. Scholarship-Funds related posts are contents regarding scholarship disbursement procedures, requirements, etc. Job related posts are information about job opportunities in Australia, salaries, and how to apply, etc. Pre-departure related posts are discussion about Visa, immigration, and other similar matters. Personal needs/daily activities include discussions about place to shop, how to travel in Australia, information related to entertainment, social activities, etc. Study process related 
posts are discussions about how to interact with supervisors, administrative procedures in campus, curricula, and all information related to the process of study.

In order to provide a semantic differentiation on the interaction within the WA group, posts from members are also categorized based on the manner of the message. I divided the category of manner of posts into: (1) informative, (2) inquisitive, (3) responsive, (4) posts with pictures or documents. The first three categories explain the manner of posts, in the form of texts, while the latter, posts with pictures or documents is special category non-comparable with the former three categories. Informative posts are information delivered by any group members without having prior question or inquiry from other group members. Inquisitive questions are posts asking for answers, while the opposite, responsive posts are posts by any group members, answering or replying inquisitive post.

I should recognize that there was a problem of quantification post categories during the observation, particularly in defining which counts as one post or many posts. This is due to the fact that members of WA group often times send similar posts in WA group but with the same content or subject of discussion without delay, using multiple 'balloons' or posts, hence deciding on how many posts count as one, or two, or three, or more, do pose quite a challenge. For this matter, I carefully count multiple posts with similar topic which are posted within an adjacent time as a single post.

Categorization of WA posts based on previous explanation can be found in Table 4 below. The category in the vertical column serve as types of category of posts while the horizontal row provides information of categorization based on manner of posts.

Table 4. Categories of Posts within WA Group

\begin{tabular}{lccccc}
\hline Category of Posts/Information & Informative & Inquisitive & Responsive & Pictures/Docs & TOTAL \\
\hline Group Related & 2 & 4 & 3 & 2 & 11 \\
Scholarship Funds Related & 20 & 13 & 19 & 11 & 63 \\
Job Related & 2 & 0 & 0 & 5 & 3 \\
Pre-Departure Related & 4 & 3 & 12 & 11 & 14 \\
Personal Needs/Daily Activities & 14 & 7 & 3 & 7 & 44 \\
Student Community related & 1 & 3 & 3 & 1 & 14 \\
Study related & 7 & 4 & 45 & 35 & 15 \\
TOTAL & 50 & 34 & & & 164 \\
\hline
\end{tabular}

Topics related to scholarship funds are the most frequently discussed, in which each member talks about how to process the disbursement of scholarship fund, troubleshooting procedures with sponsors, etc. Since the topics is of utmost importance for scholarships awardee, members talk about this topic most of the time, asking questions if one were to meet any difficulties, while others providing answers and solutions based on their past experience and knowledge on the matter. The second most discussed topics are subjects related to personal needs/daily activities, discussing about public transportation, places to shop, tourism spots and entertainment activities in Australia. The least discussed topic is Job related information. It is very interesting to find that the number of posts on this subject to be low, considering the fact that information on job opportunities is one of the required information by the member of the group (Table 2). 
There are more informative posts compared to inquisitive posts, meaning that members are willing to take initiative in posting information in the group. There are also more responsive posts, contrary to the fewer number of inquisitive posts, meaning that a single question would sometimes get more than one reply. Pictures/document posts are not categorized using the aforementioned semantics category of informative, inquisitive, and responsive posts. This is considering the fact that pictures and/or documents cannot stand alone within WA Group communication, always supported with textual information such as photo caption and other text information.

\section{Conclusions and Recommendations}

From this study, we can understand that the motivation of group members in joining the WA group is mostly related to scholarship and life in Australia. Students expect to obtain information related to life in Australia, improve networking, gain new friends, and getting help from fellow students by joining the WA Group. The information needed also related on the topics of scholarship and life in Australia, including subjects related to pre-departures such as information on visa, information related to personal needs in Australia, information on education support in Australia, family and dependants info, job opportunities, sales and trades, and information of Indonesian students' events.

Most member doesn't consider themselves as active within the group and are also undecided on whether they often post good information or not. Members don't consider the group as an important platform for social existence, also they believe that by participating in the group would be beneficial for their education in Australia, with other members always responding to questions, and they willing provide answers for questions by other members. Members don't believe that participating in the group would waste their time, and they are mostly comfortable with other members of the group.

Subjects related to scholarship funds are the most frequently discussed, and the second most discussed topics are subjects related to personal needs/daily activities. The least discussed topic is Job related information. There are more informative posts compared to inquisitive posts, meaning that members are willing to take initiative in posting information in the group. There are also more responsive posts, contrary to the fewer number of inquisitive posts, meaning that a single question would sometimes get more than one reply.

Findings on this study would serve as preliminary insights on how diaspora of Indonesian students interacts within WA Group and how they regard the importance of the platform. Due to the nature of cross-sectional data and small sample size, I am strongly advising on careful approach when generalizing or using the data in other manners. It is also interesting to see a more thorough analysis in other groups, by replicating similar questions and comparing the response based on different country of study.

\section{References}

[1] "Jumlah Pelajar Internasional ke Australia Naik di Tahun 2018," ABC News, 2018. [Online]. Available: https://www.abc.net.au/indonesian/2018-07-10/jumlah-pelajarinternasional-di-australia/9971890. [Accessed: 06-Oct-2019].

[2] M. Seufert, T. Hoßfeld, A. Schwind, V. Burger, and P. Tran-Gia, "Group-based communication in WhatsApp," 2016 IFIP Netw. Conf. (IFIP Networking) Work. IFIP Netw. 2016, pp. 536-541, 2016. 
[3] R. Fauzi, "Perubahan Budaya Komunikasi Pada Pengguna WhatsApp di Era Media Baru," JIKE, J. Ilmu Komun. Efek, vol. 1, no. 1, 2017.

[4] M. Matassi, P. J. Boczkowski, and E. Mitchelstein, "Domesticating WhatsApp: Family, friends, work, and study in everyday communication," New Media Soc., 2019.

[5] S. Blackstock, S. Solomon, M. Watson, and P. Kumar, "THE USE OF A WHATSAPP ${ }^{\mathrm{TM}}$ BROADCAST GROUP TO IMPROVE KNOWLEDGE AND ENGAGEMENT OF ADOLESCENTS WITH TYPE1 DIABETES,” J. Chem. Inf. Model., vol. 53, no. 9, pp. 1689-1699, 2013.

[6] H. Hafiar and S. Lukman, "Optimalisasi Kegiatan Promosi Melalui Grup Whatsapp ( WAG ) Dalam Menjaring Calon Peserta Pesantren Kilat Optimizing Promotional Activities Through WhatsApp Group ( WAG ) In Capturing Candidates for Boarding School Abstraksi Penelitian ini bermaksud mengu," Promedia, vol. 4, no. 1, pp. 56-75, 2018.

[7] N. Aharony and T. Gazit, "The importance of the Whatsapp family group: an exploratory analysis," Aslib J. Inf. Manag., vol. 68, no. 2, pp. 174-192, 2016.

[8] Trisnani, "WhatsApp Utilization As Media Communication and Satisfaction In Submission of Messages among People of the Community," J. Komunikasi, Media dan Inform., vol. 6, no. 3 November, pp. 1-12, 2017.

[9] A. R. Fauzi, "The development of whatsapp group discussion to solve the limitation of lecture-students interaction at class," J. Phys. Conf. Ser., vol. 1193, no. 1, 2019.

[10] S. Lukman and H. Hafiar, "Utilizing WhatsApp Group as Supplemental Communication Media During Undergraduate Thesis Supervision," in 1st International Conference on Education in Indonesia 2016, 2016.

[11] A. Sukrillah, I. Ratnamulyani, and A. Kusumadinata, "UTILIZATION OF SOCIAL MEDIA THROUGH WHATSAPP GROUP FEI AS A COMMUNICATION FACILITY," J. Komun., vol. 3, no. 2, pp. 95-104, 2017.

[12] R. Woro, Y. South, P. Online, H. Kong, and M. Post, "Indonesia' s listening in on private internet chat groups. WhatsApp with that?," pp. 1-4, 2019.

[13] D. Aizenkot and G. Kashy-Rosenbaum, "Cyberbullying in WhatsApp classmates' groups: Evaluation of an intervention program implemented in Israeli elementary and middle schools," New Media Soc., vol. 20, no. 12, pp. 4709-4727, 2018.

[14] S. Kemp, "Digital 2019: Indonesia," 2019.

[15] E. Katz, J. G. Blumler, and M. Gurevitch, The uses of mass communications: Current perspectives on gratifications research. Sage publications Thousand Oaks, CA, 1974.

[16] M. Esew, A. Makarfi, R. W. Goshie, and A. Jimada, "An Overview of Users Information Seeking Behaviour on Online Resources," IOSR J. Humanit. Soc. Sci., vol. 19, no. 1, pp. 9-17, 2014.

[17] T. Gazit and N. Aharony, "Factors explaining participation in WhatsApp groups: an exploratory study," Aslib J. Inf. Manag., vol. 70, no. 4, pp. 390-413, 2018. 